\title{
The MCDM Model for Personnel Selection Based on SWARA and ARAS Methods
}

UDC: 005.22:005.953.2

DOI: 10.7595/management.fon.2015.0029

\begin{abstract}
Competent employees are the key resource in an organization for achieving success and, therefore, competitiveness on the market. The aim of the recruitment and selection process is to acquire personnel with certain competencies required for a particular position, i.e.,a position within the company. Bearing in mind the fact that in the process of decision making decision-makers have underused the methods of making decisions, this paper aims to establish an MCDM model for the evaluation and selection of candidates in the process of the recruitment and selection of personnel based on the SWARA and the ARAS methods. Apart from providing an MCDM model, the paper will additionally provide a set of evaluation criteria for the position of a sales manager (the middle management) in the telecommunication industry which will also be used in the numerical example. On the basis of a numerical example, in the process of employment, theproposed MCDMmodel can be successfully usedin selecting candidates.
\end{abstract}

Keywords: selection of personnel, recruitment and selection, SWARA, ARAS, MCDM

\section{Introduction}

Human resource management in companies is increasingly gaining in importance and is becoming an indispensable strategic component (Djurović, 2012). As a very important factor within human resource management, the process that particularly stands out is the process of personnel recruitment and selection. A need for the selection and recruitment of personnel for a specific position occurs at the moment when a certain position becomes vacant or when a new position needs to be created due to an expansion of work within the company.

Before starting the recruitment process, it is necessary that the process of a job analysis should be conducted. A job analysis involves collecting the necessary information on a specific workplace in terms of responsibilities, the required skills, the competencies and the knowledge necessary for a potential candidate to possess (BogićevićMilikić, 2006).

Obtaining human potential is a protective activity creatingan offer of candidates from which organizations can choose new employees in case of labour shortage. The recruitment and the selection of new candidates are two complex processes (Noe et al., 2006). The process of acquiringa candidate can be accessed in two ways, i.e., throughan internal recruitment and through an external recruitment. An internal recruitment implies that, for filling a vacant position, candidates can be selected amongstthe employees within the company who have the skills and the competencies necessary for them to perform a job, whereas an external recruitment implies filling a vacant position with external applicants. According toDesler (2007), recruitment is more complex than most managers think it is. Recruiting does not only mean publishing ads or calling agencies, but it should also primarily correspond to an organization's strategic and other plans.

The selection process is important from the viewpoint of the fact that it is carried out in order to perform the final selection of the best candidates for a vacant position. In order to make decisions on which candidates better meet the requirements in terms of their possessing certain competencies, knowledge and the required criteria of a workplace, different methods and techniques can be applied in the recruitment and selection processes that will help decision makers to conduct the final selection of candidates (Petković et al., 2005; Urošević\&Sajfert, 2012). 
According to Cooper \& Robertson (1995), a decision on the selection of candidates in the recruitment and selection processes includes the use of all available sources of information on potential candidates. Using selection methods is an important precondition for making good decisions onmaking a choice; in this sense, Noah et al. (2006) note nine most frequently used methods for the selection of candidates in the recruitment and selection processes. According to him, the most important ones are: the interview, references, physical ability, acognitive test, apersonality test, samples of work tests, honesty tests and tests on drug use. Based on the above-mentioned performed tests, a lot of candidates can be rejected and the above methods certainly represent a good starting point for a selection to be made.

In order to better evaluate the candidates and determine their competencies and knowledge, ithas been noticed that a significant number of research studies into the problem of recruitment and selection use an approach based on using cognitive tests, psychometric tests, personality tests, intelligence tests, or on forming centers of competency assessment (Morgeson et al., 2007; Kruyen et al., 2012; Robertson \& Smith, 2001).

Multi-criteria decision-making (MCDM) represents one of the fastest growing fields of operations research. The MCDM has over the time found its application in solving various complex decision-making problems. In due course of time many MCDM methods have been developed such as AHP, PROMETHEE, ELECTRE, SAW, ARAS, COPRAS, MOORA, MULTIMOORA, WASPAS CP, VIKOR, TOPSIS and so on. An overview of the mentioned methods and comparisons is given by Turskis and Zavadskas (2011), Stanujkic et al. (2013), Zavadskas et al. (2014) and Mardani et al. (2015).

A number ofresearch studies have approached the selection of personnel by using the MCDM methods such as the SWARA method used for the selection of personnel (Zolfani\&Banihashemi, 2014), the ARAS method applied to selection of the chief accountant (Keršulienë\&Turskis, 2014), creating a fuzzy model for the selection of personnel (Petrović-Lazarević, 2001) and the application of the AHP method in a fuzzy environment for the selection of a personnel problem (Güngör et al., 2009) and so on.

The applied MCDM model is based on the use of the SWARA and the ARAS methods, where the SWARA method is used for determining criteria weights and the ARAS method is used for a further evaluation of alternatives in relation to the selected set of criteria. In order to form an easy-to-use approach:

- the SWARA method is chosen instead of the most commonly used AHP method, due to considerably lower pairwise comparison and ease of use,

- the ARAS method is also chosen because of its simplicity compared to other MCDM methods such as the TOPSIS method proposed by Hwang and Yoon (1981), the PROMETHEE method proposed by Brans and Vicke (1985) and the VIKOR method proposed by Opricovic (1998).

Finally, the complete process of selection of candidates, including the determining criteria weight and evaluation of alternatives, can be done by usingonly the AHP method but this approach involves a much larger number of pairwise comparisons and can be uncomfortable for respondents.

The paper will be organized as follows: in Section 1the introductory considerations will be given;Section 2 will provide an overview of the relevant criteria to be applied in a numerical example; Section 3 will present the SWARA method;Section 4 will demonstrate the ARAS method; in Section 5anumerical example of the application of these methods will be presented, and Section 6 is the conclusion.

\section{Evaluation criteria for the position of a sales manager}

A set of necessary competencies and required skills necessary for a sales manager to possess are significant from the standpoint of the company's achieving success and good sales results, and consequently a more favourable competitive position. For that reason, recruiters always strive to fill vacant positions with candidates who best meet the evaluation criteria, with a particular emphasis on theirhavingthe necessary required competencies.

In their study,Rentz et al. (2002)note that one's possessing necessary sales competencies leads to ahigher efficiency. So, the selection of the candidates who possess the necessary competencies that characterize a sales manager positively reflects on sales effectiveness, and it is reasonable to assume that it will lead to 
better corporate results.

Evaluation criteria in the recruitment and selection process are usually created according to the defined requirements of the job and after conducting a job analysis. It is important that weshould note that the models of evaluation criteria and competencies vary according to the position; however, there are cases when the position is the same but within different sectors of the economy, in which case evaluation criteria and competencies also change: e.g.,a sales manager in the telecommunication industry and a sales manager in the furniture manufacturing industry have notably the same position but there are respectively different evaluation criteria followed by decisionmakers in the employment process.

The approach to the issue of the selection of criteria for a particular position varies from one author to another, so, in their study,Popović et al. (2012) elicit the key competencies of a business manager on the basis of reviewed literature (Biesma et al., 2007; Ruetzler et al., 2010), and in the conducted research, theyselected the key attributes such as education, work experience, knowledge of foreign languages, computer skills, communication skills, problem solving skills and creativity, team working skills, organizational skills, proactivity and interview preparedness. In his skills matrix for the position of a marketing manager,Desler (2007)emphasizes the following important skills such as the technical ability, business awareness, communication and interpersonal skills, decision making and initiatives, management and advising, organizational skills and the planning capability and problem solving. In their study of the application of the intuitionistic fuzzy TOPSISmethod for the selection of a sales manager,Boran et al. (2011)use the following criteria:the oral communication skills, past experience, a general aptitude, willingness, self-confidence and the first impression. Hill \& Birdseye (1989) indicate some of the selection criteria for the selection of personnel in sales such as education, interviews, previous experience, personal appearance and references.

Therefore, on the basis of the studied literature and the conducted research, the authors of this study on the selection of a sales manager propose the following model of evaluation criteria as shown in Table 1, which will also be used in the numerical example.

Table 1. The set of the evaluation criteria

\begin{tabular}{lll}
\hline & Criteria & Designation \\
\hline$C_{1}$ & Relevant work experience & $W e$ \\
$C_{2}$ & Proactivity and general aptitude & $\mathrm{Pr}$ \\
$C_{3}$ & Organizational and analytical skills & $\mathrm{Os}$ \\
$C_{4}$ & Education & Ed \\
$C_{5}$ & Communication and problem solving skills & $\mathrm{Cp}$ \\
$C_{6}$ & Computer skills & $\mathrm{Cs}$ \\
\hline
\end{tabular}

\section{The Step-wise Weight Assessment Ratio Analysis}

TheStep-wise Weight Assessment Ratio Analysis (SWARA) is developed by Kersulieneet al. (2010). The SWARA method has attracted a significant attention when its application is concerned and when it comes to solving different problems such as a machine tool selection (Aghdaie et al. 2013), personnel selection (Zolfani\&Banihashemi, 2014; Kersuliene\&Turskis 2011), corporate social responsibility and sustainability (Karabašević et al., 2015; Zolfani\&Saparauskas, 2013), the design of products (Zolfaniet al., 2013) and the selection of a packaging design (Stanujkic et al., 2015).

The algorithm for determining the relative weights of the criteria by applying the SWARA method based onKersuliene et al. (2010) and Stanujkic et al. (2015) is shown by using the following steps:

Step 1. The criteria are sorted in a descending order, based on their expected significances.

Step 2. Starting from the second criterion, the respondent expresses the relative importance of the criterion $j$ in relation to the previous $(j-1)$ criterion, and does so for each particular criterion. According to Kersulieneet al. (2010), this ratio is called the Comparative Importance of the Average Value, $s_{j}$. 
Step 3. Determine the coefficient $k_{j}$ as follows:

$$
k_{j}=\left\{\begin{array}{cc}
1 & j=1 \\
s_{j}+1 & j>1
\end{array} .\right.
$$

Step 4. Determine the recalculated weight $q_{j}$ as follows:

$$
q_{j}=\left\{\begin{array}{cc}
1 & j=1 \\
\frac{q_{j-1}}{k_{j}} & j>1
\end{array} .\right.
$$

Step 5. The relative weights of the evaluation criteria are determined as follows:

$$
w_{j}=\frac{q_{j}}{\sum_{k=1}^{n} q_{k}},
$$

wherew $w_{j}$ denotes the relative weightof the $j$-th criterion, and $n$ denotes the number of the criteria.

\section{A new Additive Ratio Assessment method}

The new Additive Ratio Assessment (ARAS) method is developed by Zavadskas\&Turskis (2010). Although it is a newly-proposed method, the ARAS method is an effective and easy to use MCDM method. The effectiveness and usefulness of the mentioned method is confirmed by its extensions, such as an extension of the method with grey numbers ARAS-G (Turskis\&Zavadskas, 2010) and an extension with the use of interval-valued triangular fuzzy numbers (Stanujkic, 2015).

Similarily to the SWARA method, the ARAS method has also been used for solving many MCDM problems in different areas such as the selection of the chief accountant (Kerðulienë, Turskis, 2014), the ranking of financial institutions (Reza \& Majid, 2013) and problems related to construction (Medineckiene et al., 2015).

Based on Stanujkic and Jovanovic (2012), the procedure of solving MCDM problems by applying the ARAS method in some cases when an MCDM problem only includes benefit criteria, can be precisely described by using the following steps:

Step1: Determine the optimal performance rating for each criterion. After creating a decision matrix, the next step in the ARAS method is to determine the optimal performance rating for each criterion. If decision makers do not have preferences, the optimal performance ratings are calculated as:

$$
x_{0 j}=\max _{i} x_{i j}
$$

where $^{x_{0 j}}$ is the optimal performance rating in relation to the $j$-th criterion. follows:

Step2: Calculate a normalized decision matrix. Normalized performance ratings are calculated as

$$
r_{i j}=\frac{x_{i j}}{\sum_{i=0}^{m} x_{i j}},
$$

where ${ }^{r_{i j}}$ is the normalized performance rating of thei-th alternative in relation to the $j$-th criterion.

Step 3: Calculate a weighted normalized decision matrix. The weighted normalized performance ratings are calculated as follows: 


$$
v_{i j}=w_{j} \cdot r_{i j},
$$

where ${ }^{w_{j}}$ denote weight of the $j$-th criterion, $v_{i j}$ is the weighted normalized performance rating of the $i$-th alternative in relation to the $j$-th criterion.

Step4:Calculate the overall performance indexfor each alternative.The overall performance index

$S_{i}$ for each alternative can be calculated as the sum of the weighted normalized performance ratings, as follows:

$$
S_{i}=\sum_{j=1}^{n} v_{i j}
$$

Step5: Calculate the degree of utility for each alternative. When evaluating alternatives with the candidates in the recruitment and selection processes in our case, it is not only important that the best-ranked alternative/candidate should be determined, but also that the relative performances of the considered alternatives/candidates should be determined in relation to the best-ranked alternative/candidate. For this purpose, it is needed that we use a degree of utility, which can be calculated as follows:

$$
Q_{i}=\frac{S_{i}}{S_{0}}
$$

where $Q_{i}$ is the degree of the utility of thei-th alternative, and $S_{0}$ is the overall performance index of the optimal alternative, which is usually 1 .

Step6:Rank the alternatives and/or select the most efficient one.The considered alternatives are ranked by ascending $Q_{i}$, i.e., the alternatives with the higher values of $Q_{i}$ have a higher priority (rank) and the alternative with the largest value of $Q_{i}$ is the best-placed one.

\section{A numerical example}

To present the efficiency and simplicity of the proposed approach, a numerical example is shown in this section. In order to determine the weights of the evaluation criteria, the team of three human resource decision-making experts (HR DM) is formed. The team will have a task to evaluate four candidates and choose the best one.The evaluation of candidates in relation to the selected criteria is performed by applying ratings in an interval of $1-5$. The stances of the first expert, as well as the calculated weight of the criteria, are accounted for in Table 2.

Table 2. The resulting weight of the criteria obtained from the first of the three HR DMs

\begin{tabular}{llllll}
\hline & Criteria & $s_{j}$ & $k_{j}$ & $q_{j}$ & $w_{j}$ \\
\hline$C_{1}$ & Relevant work experience & & 1 & 1 & 0.25 \\
$C_{2}$ & Proactivity and general aptitude & 0.15 & 1.15 & 0.87 & 0.22 \\
$C_{3}$ & Organizational and analytical skills & 0.3 & 1.3 & 0.67 & 0.17 \\
$C_{4}$ & Education & 0.05 & 1.05 & 0.64 & 0.16 \\
$C_{5}$ & Communication and problem solving skills & 0.35 & 1.35 & 0.47 & 0.12 \\
$C_{6}$ & Computer skills & 0.7 & 1,7 & 0.28 & 0.07 \\
\hline & & & & 3.92 & 1.00 \\
\cline { 5 - 6 }
\end{tabular}


The values in column $s_{j}$ represent the stances of the HR DMexpert, i.e., the values given by experts. The values in columns $k_{j}, q_{j}$ and $w_{j}$ are obtained by using Eqs. (1), (2) and (3). The stances of the second and the third HR DM experts are shown in Tables 3 and 4, as well as the corresponding weights of the criteria.

Table 3. The resulting weight of the criteria obtained from the second of the three HR DMs

\begin{tabular}{|c|c|c|c|c|c|}
\hline & Criteria & $s_{j}$ & $k_{j}$ & $q_{i}$ & $w_{j}$ \\
\hline$C_{1}$ & Relevant work experience & & 1 & 1 & 0.30 \\
\hline $\mathrm{C}_{2}$ & Proactivity and general aptitude & 0.2 & 1.2 & 0.83 & 0.25 \\
\hline$C_{3}$ & Organizational and analytical skills & 0.4 & 1.4 & 0.60 & 0.18 \\
\hline $\mathrm{C}_{4}$ & Education & 0.5 & 1.5 & 0.40 & 0.12 \\
\hline$C_{5}$ & Communication and problem solving skills & 0.1 & 1.1 & 0.36 & 0.11 \\
\hline \multirow[t]{2}{*}{$C_{6}$} & Computer skills & 0.8 & 1.8 & 0.20 & 0.06 \\
\hline & & & & 3.39 & 1.00 \\
\hline
\end{tabular}

Table 4. The resulting weights of the criteria obtained from the third of the three HR DMs

\begin{tabular}{llllll}
\hline & Criteria & $s_{i}$ & $k_{j}$ & $q_{i}$ & $w_{i}$ \\
\hline$C_{1}$ & Relevant work experience & & 1 & 1 & 0.24 \\
$C_{2}$ & Proactivity and general aptitude & 0.05 & 1.05 & 0.95 & 0.23 \\
$C_{3}$ & Organizational and analytical skills & 0.25 & 1.25 & 0.76 & 0.18 \\
$C_{4}$ & Education & 0.05 & 1.05 & 0.73 & 0.17 \\
$C_{5}$ & Communication and problem solving skills & 0.5 & 1.5 & 0.48 & 0.12 \\
$C_{6}$ & Computer skills & 0.75 & 1.75 & 0.28 & 0.07 \\
\hline & & & 4.20 & 1.00 \\
\hline
\end{tabular}

After the process has been completed, the overall weight of the evaluation criteria is determined as a geometric mean of the weights obtained from the $3 \mathrm{HR}$ DMs, that is as follows:

$$
w_{j}=\left(\prod_{k=1}^{K} w_{j}^{k}\right)^{\frac{1}{K}},
$$

where $w_{j}^{k}$ is the relative criteria weight of $j$-th criterion, obtained on the basis of pairwise comparisons of the $k$-th decision maker, and Kdenotes a number of decision makers.

In Table 5, the weights of the evaluation criteria can be seen.

Table 5. The weights of the evaluation criteria

\begin{tabular}{lll}
\hline & Criteria & $w_{i}$ \\
\hline$C_{1}$ & Relevant work experience & 0.26 \\
$C_{2}$ & Proactivity and general aptitude & 0.23 \\
$C_{3}$ & Organizational and analytical skills & 0.18 \\
$C_{4}$ & Education & 0.15 \\
$C_{5}$ & Communication and problem solving skills & 0.11 \\
$C_{6}$ & Computer skills & 0.07 \\
\hline
\end{tabular}

The ratings of the four candidates, obtained from the three HR DM experts are accounted forin Tables 6, 7 and 8. 
Table 6. The data obtained from the first HR DM

\begin{tabular}{lllllll}
\hline & We & $P r$ & Os & $E d$ & $C p$ & $C s$ \\
\hline$A_{1}$ & 2 & 3 & 3 & 2 & 4 & 3 \\
$A_{2}$ & 5 & 4 & 5 & 4 & 5 & 4 \\
$A_{3}$ & 4 & 3 & 2 & 2 & 3 & 4 \\
$A_{4}$ & 1 & 3 & 2 & 2 & 2 & 3 \\
\hline
\end{tabular}

Table 7. The data obtained from the second HR DM

\begin{tabular}{lllllll}
\hline & We & $P r$ & Os & $E d$ & $C p$ & $C s$ \\
\hline$A_{1}$ & 1 & 3 & 2 & 2 & 3 & 2 \\
$A_{2}$ & 5 & 3 & 5 & 5 & 3 & 5 \\
$A_{3}$ & 3 & 3 & 2 & 4 & 3 & 3 \\
$A_{4}$ & 2 & 2 & 3 & 3 & 2 & 4 \\
\hline
\end{tabular}

Table 8. The data obtained from the third HR DM

\begin{tabular}{lllllll}
\hline & $W e$ & $P r$ & $O s$ & $E d$ & $C p$ & $C s$ \\
\hline$A_{1}$ & 2 & 1 & 3 & 2 & 2 & 3 \\
$A_{2}$ & 4 & 5 & 4 & 5 & 4 & 5 \\
$A_{3}$ & 2 & 3 & 2 & 2 & 2 & 3 \\
$A_{4}$ & 1 & 2 & 3 & 3 & 3 & 3 \\
\hline
\end{tabular}

The overall ratings of the evaluated candidates are determined as a geometric mean of the grades obtained from the HR DM experts, which is as follows:

$$
x_{i j}=\left(\prod_{k=1}^{K} x_{i j}^{k}\right)^{\frac{1}{K}},
$$

where $x_{i j}$ denotes average ratings ofi-th alternative in relation to $j$-th criterion, ${ }^{k}{ }_{i j}^{k}$ denotes ratings of $i$-th alternative in relation to $j$-th criterion from $k$-th decision maker, and Kdenotes the number of decision makers.

Table 9 shows the weights of the evaluation criteria.

Table 9. The average grading of the candidates

\begin{tabular}{lllllll}
\hline & $W e$ & $P r$ & Os & $E d$ & $C p$ & $C s$ \\
\hline$A_{0}$ & 4.64 & 3.91 & 4.64 & 4.64 & 3.91 & 4.64 \\
$A_{1}$ & 1.59 & 2.08 & 2.62 & 2.00 & 2.88 & 2.62 \\
$A_{2}$ & 4.64 & 3.91 & 4.64 & 4.64 & 3.91 & 4.64 \\
$A_{3}$ & 2.88 & 3.00 & 2.00 & 2.52 & 2.62 & 3.30 \\
$A_{4}$ & 1.26 & 2.29 & 2.62 & 2.62 & 2.29 & 3.30 \\
\hline
\end{tabular}

Table 9 also shows the optimal performance ratings, in row $A_{0}$, obtained by using Eq. (4).

The normalized ratings, determined by using Eq. (5), are presented in Table 10.Table 10 also showsthe weights of the criteria.

Table 10. The normalized decision-making matrix

\begin{tabular}{lllllll}
\hline & We & Pr & Os & $E d$ & $C p$ & $C s$ \\
\hline$w_{i}$ & 0.26 & 0.23 & 0.18 & 0.15 & 0.11 & 0.07 \\
\hline$A_{0}$ & 0.31 & 0.26 & 0.28 & 0.28 & 0.25 & 0.25 \\
$A_{1}$ & 0.11 & 0.14 & 0.16 & 0.12 & 0.18 & 0.14 \\
$A_{2}$ & 0.31 & 0.26 & 0.28 & 0.28 & 0.25 & 0.25 \\
$A_{3}$ & 0.19 & 0.20 & 0.12 & 0.15 & 0.17 & 0.18 \\
$A_{4}$ & 0.08 & 0.15 & 0.16 & 0.16 & 0.15 & 0.18 \\
\hline
\end{tabular}


The overall performance of the evaluated alternatives obtained by using Eqs. (7) and (8) are shown in Table 11.

Table 11. The overall results of the ranked alternatives

\begin{tabular}{llll}
\hline & $S_{i}$ & $Q_{i}$ & Rank \\
\hline$A_{0}$ & 0.28 & & \\
$A_{1}$ & 0.14 & 0.49 & 4 \\
$A_{2}$ & 0.28 & 1.00 & 1 \\
$A_{3}$ & 0.17 & 0.62 & 2 \\
$A_{4}$ & 0.14 & 0.49 & 3 \\
\hline
\end{tabular}

According to Table 11, the candidate designated as $A_{2}$ has the highest overall importance and therefore the best results in terms of the evaluated criteria

\section{Conslusion}

In today's business conditions, human resources represent one of the main strategic resources of a company. The selection of the personnel who need to be competent and motivated poses a major challenge companies are faced with today. Employees' competencies are of great significance for a company, especially in terms of increased market competition; so, precisely for this reason, decision makers increase their focus in the recruitment and selection processeson the selection of candidates with better competencies.Accordingly, the paper suggests a model of the evaluation criteria for the position of a sales manager. The conducted research and the numerical example show that the MCDM modelbased on the SWARAARAS methods can be applied in order to solve problems in the field of the selection and evaluation of candidates in the employment process. On the basis of the numerical example,a conclusion can be drawnthat the proposed SWARA-ARAS model is simple, easy to use, applicable and adaptable. Modified to a certain extent, the mentioned model can easily be adapted and could solve problems in other areas as well. As a direction for future research, other MCDM methods, such as the MULTIMOORA and the WASPAS ones, can be used in order to solve similar problems.

\section{REFERENCES}

[1] Aghdaie, M. H., Zolfani, S. H. \&Zavadskas, E. K. (2013).Decision making in machine tool selection: An integrated approach with SWARA and COPRAS-G methods. InzinerineEkonomika - Engineering Economics, 24(1), 5-17.

[2] Biesma, R. G., Pavlova, M., Merode Van G. G. \& Groot, W. (2007). Using conjoint analysis to estimate employers preferences for key competencies of master level Dutch graduates entering the public health field. Economics of Education Review, 26, 375-386.

[3] BogićevićMilikić, B. (2006). Menadzmentljudskihresursa. Ekonomskifakultet, Beograd.

[4] Boran, F. E., Genc, S. \&Akay, D. (2011). Personnel Selection Based on Intuitionistic Fuzzy Sets. Human Factors and Ergonomics in Manufacturing \& Service Industries, 21 (5), 493-503.

[5] Brans, J. P. \&Vincke, P. (1985). A preference ranking organization method: The PROMETHEE method for MCDM, Management Science, 31(6), 647-656.

[6] Cooper, D., Robertson I. T. (1995). The psychology of personnel selection: A quality approach. Routledge, London

[7] Desler G. (2007). Osnovimenadžmentaljudskihresursa. Data Status, Beograd.

[8] Đurović, M. (2012). Menadžmentljudskihresursa - strateškiaspekt. Management časopissateorijuipraksumenadžmenta. 62, 95-101.

[9] Güngör, Z., Serhadlıoğlu, G. \&Kesen S. E. (2009). A fuzzy AHP approach to personnel selection problem. Applied Soft Computing, 9(2), 641-646.

[10] Hill, J. \& Birdseye, M. (1989). Salesperson Selection in Multinational Corporations: An empirical study. Journal of Personal Selling \& Sales Management, 9, 39-47.

[11] Hwang, C. L. \& Yoon, K. (1981). Multiple Attribute Decision Making - Methods and Applications. Springer. $259 \mathrm{p}$.

[12] Karabašević, D., Paunković, J. \&Stanujkić, D. (2015 accepted) Ranking of companies according to the indicators of corporate social responsibility based on SWARA and ARAS methods. Serbian Journal of Management, in press. 
[13] Keršulienè, V. \&Turskis, Z. (2011). Integrated fuzzy multiple criteria decision making model for architect selection. Technological and Economic Development of Economy, 17(4), 645-666.

[14] Keršulienè, V. \&Turskis, Z. (2014). An integrated multi-criteria group decision making process: selection of the chief accountant. Procedia - Social and Behavioral Sciences, 110, 897-904.

[15] Kersuliene, V., Zavadskas, E. K. \&Turskis, Z. (2010). Selection of rational dispute resolution method by applying new step - wise weight assessment ratio analysis (SWARA). Journal of Business Economics and Management, 11(2), 2010, 243-258.

[16] Kruyen, P. M., Emons, W. H. M. \&Sijtsma, K. (2012). Test Length and Decision Quality in Personnel Selection: When Is Short Too Short? International Journal of Testing, 12(4), 321-344.

[17] Mardani, A., Jusoh, A., MD Nor, K., Khalifah, Z.,Zakwan, N., Valipour, A. (2015). Multiple criteria decision-making techniques and their applications-a review of the literature from 2000 to 2014. Economic Research - Ekonomskalstrazivanja, 28(1), 516-571.

[18] Medineckienea, M., Zavadskas, E. K., Björka, F. \&Turskis, Z. (2015). Multi-criteria decision-making system for sustainable building assessment/certification. Archives of Civil and Mechanical Engineering, 15(1), 11-18.

[19] Morgeson, F. P., Campion, M. A., Dipboye, R. L., Hollenbeck, J. R. Murphy, K. \& Schmitt, N. (2007). Reconsidering the use of personality tests in personnel selection contexts. Personnel Psychology, 60(3), 683-729.

[20] Noe A. R., Hollenbeck, R. J., Gerhart B. \& Wright M. P. (2006). Menadžmentljudskihpotencijala-Postizanjekonkurentskeprednosti, Mate, Zagreb.

[21] Opricovic. (1998). Multi-criteria optimization of civil engineering systems, Faculty of Civil Engineering, Belgrade.

[22] Petković M., Janićijević N. \&BogićevićMilikić B. (2005). Organizacija. Ekonomskifakultet, Beograd.

[23] Petrovic-Lazarevic, S. (2001). Personnel selection fuzzy model. International Transactions in Operational Research, 8(1), 89-105.

[24] Popović, M., Kuzmanović, M. \&Martić, M. (2012). Određivanjepreferencijaključnihkompetencijabiznismenadžeraodstranedonosiocaodluke o zapošljavanjukorišćenjem Conjoint analize. Management, 63, 17-26.

[25] Rentz, J. O., Shepherd, D. C, Tashchian, A., Dabholkar, P. A. \& Ladd R. T. (2002). A Measure of Selling Skill: Scale Development and Validation. Journal of Personal Selling \& Sales Management, 22 (1), 1321.

[26] Reza, S. \& Majid, A. (2013). Ranking Financial Institutions Based on of Trust in online banking Using ARAS and ANP Method. International Research Journal of Applied and Basic Sciences, 6(4), 415-423.

[27] Robertson, I. T. \& Smith, M. (2001). Personnel selection, Journal of Occupational and Organizational Psychology, 74(4), 441-472.

[28] Ruetzler, T., Taylor, J., Reynolds, D. \& Baker, W. (2010). Assessing Professional Attributes using Conjoint Analysis. International CHRIE Conference, 28-31 July, 2010. International CHRIE Conference-Refereed Track. Paper 12.

[29] Stanujkić, D. \& Jovanovic. R. (2012). Measuring a Quality of Faculty Website Using ARAS Method. in Proc. of International scientific conference Contemporary Issues in Business, Management and Educatio '2012, selected papers, Vilnius Gediminas Technical University, Lithuania, 545-554.

[30] Stanujkić, D. (accepted, 2015). Extension of the ARAS Method for Decision-Making Problems with Interval-Valued Triangular Fuzzy Numbers. Informatica. In press.

[31] Stanujkic, D., Djordjevic, B., Djordjevic, M. (2013). Comparative analysis of some prominent MCDM methods: A case of ranking Serbian banks. Serbian journal of management, 8(2), 213-241.

[32] Stanujkić. D., Karabašević, D. \&Zavadskas, E. K. (2015). A framework for the selection of a packaging design based on the SWARA method. InzinerineEkonomika -Engineering Economics, 26(2), 181-187.

[33] Turskis, Z. \&Zavadskas, E. K. (2010). A novel method for Multiple Criteria Analysis: Grey Additive Ratio Assessment (ARAS-G) method. Informatica 21(4), 597-610.

[34] Turskis, Z., Zavadskas, E. K. (2011). Multiple criteria decision making (MCDM) methods in economics: an overview. Technological and economic development of economy, (2), 397-427.

[35] Urošević, S., Sajfert, Z. (2012). Menadžmentljudskihresursa. Don Vas, Beograd.

[36] Zavadskas, E. K. \&Turskis, Z. (2010). A new additive ratio assessment (ARAS) method in multicriteria decision-making. Technological and Economic Development of Economy, 16(2), 159-172.

[37] Zavadskas, E. K., Turskis, Z., Kildienè, S. (2014). State of art surveys of overviews onMCDM/MADM methods. Technological and Economic Development of Economy, 20(1),165-179. 
[38] Zolfani, S. H. \&Banihashemi, S.S.A. (2014). Personnel selection based on a novel model of game theory and MCDM approaches. In Proc. of 8th International Scientific Conference "Business and Management 2014", Vilnius, Lithuania, 191-198.

[39] Zolfani, S. H. \&Saparauskas, J. (2013). New Application of SWARA Method in Prioritizing Sustainability Assessment Indicators of Energy System. Engineering Economics, 24(5), 408-414.

[40] Zolfani, S.H., Zavadskas, E. K. \&Turskis, Z. (2013). Design of products with both International and Local perspectives based on Yin-Yang balance theory and SWARA method. Ekonomskaistraživanja-Economic Research, 26(2), 153-166.

Receieved: September 2015. Accepted: December 2015.

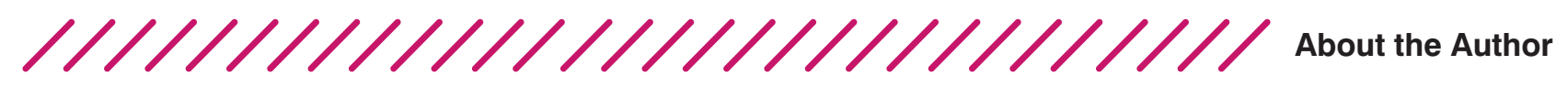

\author{
Darjan Karabasevic \\ Vip mobile d.o.o. Belgrade, Serbia \\ darjankarabasevic@gmail.com
}

Darjan Karabašević is a PhD candidate at the Faculty of Management in Zaječar, John Naisbitt University Belgrade (Megatrend University). He works as a shop manager at the Vip mobile d.o.o. telecommunication company, which is a member of the Telekom Austria Group. He obtained his degrees at all the levels of studies (B.Sc. appl. in Economics, B.Sc. in Economics and Academic Specialization in the Management of Business Information Systems) at the Faculty of Management in Zaječar, Megatrend University Belgrade. His current research is focused on the HRM, management, decision-making theory, sustainability and the CSR.

\title{
Dragisa Stanujkic John Naisbitt University, Faculty of Management inZajecar, Serbia dragisa.stanujkic@fmz.edu.rs
}

DragišaStanujkić is an associate professor of Information Technology and Decision Sciences at the Faculty of Management in Zaječar, Megatrend University, Serbia. He has received his MSc degree in Information Science and $\mathrm{PhD}$ in Organizational Sciences from the Faculty of Organizational Sciences, University of Belgrade. His current research is on decision-making theory, expert systems and intelligent decision support systems.

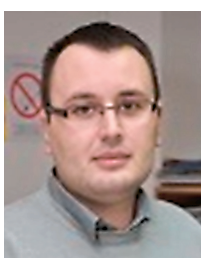

$$
\begin{array}{r}
\text { Snezana Urosevic } \\
\text { University of Belgrade, Technical Faculty in Bor, Serbia } \\
\text { surosevic@tf.bor.ac.rs }
\end{array}
$$

SnežanaUrošević is an associate professor. She defended her doctoral thesis in the field of management at the Technical Faculty "Mihajlo Pupin" in Zrenjanin, University of Novi Sad,in 2007. She has published 15 papers in international SCI journals. She is a member of the editorial boards of several national and international journals, a member of the scientific boards of several international conferences, and is currently a researcher in two national projects. Her areas of interest include Human Resource

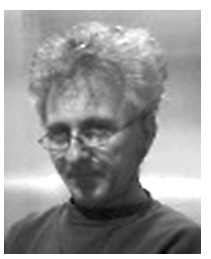
Management and Environmental Management. 